\title{
The (in)visibility of the gods in the Greco-Roman world and of God in Hellenistic Judaism: A comparison
}

\begin{tabular}{|c|c|}
\hline \multicolumn{2}{|c|}{$\begin{array}{l}\text { Author: } \\
\text { Dirk van der Merwe }{ }^{1}\end{array}$} \\
\hline \multicolumn{2}{|c|}{$\begin{array}{l}\text { Affiliation: } \\
{ }^{1} \text { Department of Christian } \\
\text { Spirituality, Church History } \\
\text { and Missiology, School of } \\
\text { Humanities, University of } \\
\text { South Africa, South Africa }\end{array}$} \\
\hline \multicolumn{2}{|c|}{$\begin{array}{l}\text { Note: } \\
\text { This article is part of a paper } \\
\text { read at the SPIRASA annual } \\
\text { conference at Unisa, Pretoria, } \\
\text { August } 2014 \text {. }\end{array}$} \\
\hline \multicolumn{2}{|c|}{$\begin{array}{l}\text { Correspondence to: } \\
\text { Dirk van der Merwe }\end{array}$} \\
\hline \multicolumn{2}{|c|}{$\begin{array}{l}\text { Email: } \\
\text { vdmerdg@unisa.ac.za }\end{array}$} \\
\hline \multicolumn{2}{|c|}{$\begin{array}{l}\text { Postal address: } \\
189 \text { Kotie Avenue, } \\
\text { Murrayfield 0184, Pretoria }\end{array}$} \\
\hline \multicolumn{2}{|c|}{$\begin{array}{l}\text { Dates: } \\
\text { Received: } 09 \text { Oct. } 2014 \\
\text { Accepted: } 30 \text { Jan. } 2015 \\
\text { Published: } 26 \text { Oct. } 2015\end{array}$} \\
\hline \multicolumn{2}{|c|}{$\begin{array}{l}\text { How to cite this article: } \\
\text { Van der Merwe, D., 2015, } \\
\text { 'The (in)visibility of the gods } \\
\text { in the Greco-Roman world } \\
\text { and of God in Hellenistic } \\
\text { Judaism: A comparison', } \\
\text { HTS Teologiese Studies/ } \\
\text { Theological Studies 71(1), } \\
\text { Art. \#2839, } 8 \text { pages. http:// } \\
\text { dx.doi.org/10.4102/hts. } \\
\text { v71i1.2839 }\end{array}$} \\
\hline \multicolumn{2}{|c|}{$\begin{array}{l}\text { Copyright: } \\
\text { (C) 2015. The Authors. } \\
\text { Licensee: AOSIS } \\
\text { OpenJournals. This work i } \\
\text { licensed under the Creativ } \\
\text { Commons Attribution } \\
\text { License. }\end{array}$} \\
\hline \multicolumn{2}{|l|}{ Read online: } \\
\hline 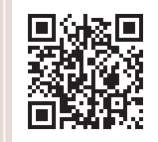 & $\begin{array}{l}\text { Scan this QR } \\
\text { code with your } \\
\text { smart phone or } \\
\text { mobile device } \\
\text { to read online. }\end{array}$ \\
\hline
\end{tabular}

The attribute of (in)visibility of a reckoned divine being is one that is not discussed often; it is one of the more obscure attributes of deities and not an easy subject to embark upon. Not much data is available on this subject, and the available information often seems contradictory. This article investigates briefly the references concerning the (in)visibility of the gods in the GrecoRoman world as well as the (in)visibility of God in Hellenistic Judaism. In order to gain more clarity, the investigation examines what the 'seeing' of the god(s) comprises in the mythology of Homer, the philosophers, the mystery religions and Hellenistic Gnosticism. In Hellenistic Judaism the focus will be on Philo as the ideal exponent.

\section{Introduction}

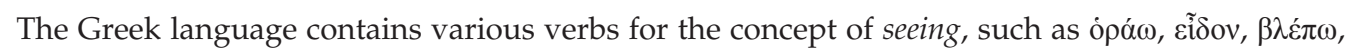

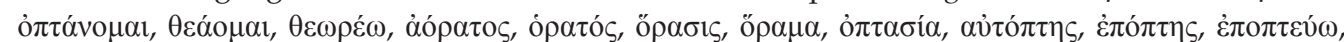

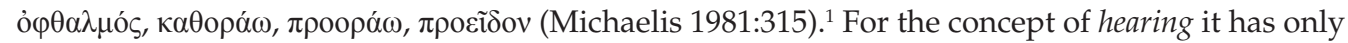

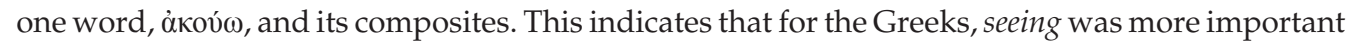
than hearing (Michaelis 1981:316). ${ }^{2}$ The various words for seeing are definitely not synonymous, but rather express different forms of seeing (Farrell 1992). It happened that some interchanging of meaning of some of these words took place over a period of time. Different verbs that originally denoted particular actions were combined into a single system of modification from their basic

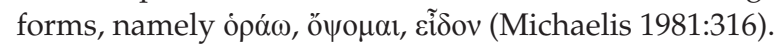

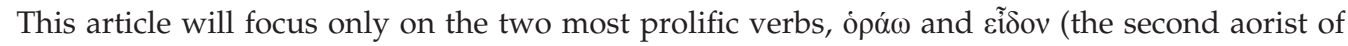
óx́(, Danker 2000:279), ${ }^{3}$ which were used in the Greco-Roman world, Hellenistic Judaism, the Septuagint (LXX) and the New Testament when reference was made to the (in)visibility of the gods/God. ${ }^{4}$ This article will focus on how these two verbs (ópó $\omega$ and $\varepsilon \tilde{i} \delta o v$ ) were used in the Greco-Roman world and in Hellenistic Judaism when reference was made to the seeing (the [in] visibility) of the god(s)/God.

\section{The (in)visibility of the gods in the Greco-Roman world ${ }^{5}$}

Spiritual vision was prominent in Hellenistic literature. The many verbs for seeing and their wide and varied range of meaning, indicate the high regard for seeing among the Greeks. Rudberg (1942:162; quoted by Michaelis 1981:319) refers to the Greeks as 'a people of the eye'. Therefore, the Greek religion 'may be regarded as a religion of vision' (Michaelis 1981:319).

This leads to the question whether deities or divine beings can be seen. Even though the anthropomorphic idea of the gods in Greek mythology and poetry allows for the supposition that they are visible to human eyes, fundamental uncertainties do exist in this regard (Michaelis 1981:319). According to Homer, a deity ${ }^{6}$ usually approaches a person in human form (Hom., Od. 1, 96ff.; 2, 267f.; 22, 205f.; cf. also Ovid, Metam. 3.251-313), but may disappear in the form of a bird to reveal his or her identity, as in the case of the goddesses Minerva ${ }^{7}$ and Athena (Hom., Od. 1, 319). Homer further states that the gods show themselves to an elect few only (with the exception

\footnotetext{
1.See the entries of Michaelis (1981:315-366), Dahn (1978:511-518), and Liefeld (1978:518-519), as well as the three articles of Farre (1992) for further and comprehensive discussions on 'seeing'

2.See Stanford ([1983] 2014) for an argument that hearing was more important than seeing.

3.See also Friberg, Friberg and Miller (2000:130) and Balz and Schneider (1990:385).

4.This article was read at the annual national conference of the Spirituality Association of South Africa, Pretoria, Unisa, 2014.

5.Influenced by Keener (2003:247ff.) and Michaelis (1981:315-366).

6.For Homer the gods were immortal (Hom., Od. 8, 101). See also Ovid (Metam. 1.1) and Callimachus (Hymn to Zeus 1.9).

7.Minerva flew away once as a swallow and another time as an eagle.
} 
in Hom., Od. 7, 201ff. $)^{8}$, and that they do this in such a way that other people remain unaware of their presence (Hom., Od. 16, 159-162). The statement of Homer, that 'the gods do not let themselves be seen by everybody' (160-161), probably implies supernatural or visionary perception. ${ }^{9}$

Homer (Hom., Od. 1, 323, cf. 19, 36) often put emphasis on 'the fear and terrible astonishment ${ }^{10}$ which seize men when the deity discloses itself'. However, we find in Homer no reference that the person who has seen a deity must die. Michaelis (1981:320) is of the opinion that the poetic style of the text makes the nature of the seeing in these theophanies imprecise. This is probably due to the fact that in mythology there is no direct visibility of the gods.

During early antiquity, Empedocles, ${ }^{11}$ one of the earliest philosophers who lived during the 5th century BCE, accentuated the invisibility of the gods. Michaelis (1981:321) quotes Empedocles (Emped., Fr. 133) by saying that 'one cannot bring the deity near to oneself as accessible to our eyes, or touch it with the hands'. Korteweg (1979:64-67) also points to Socrates who reasoned that the gods were invisible to humans and could only be contemplated through their works.

During the time of Plato ${ }^{12}$ 'seeing' and 'hearing' were regarded as important instruments of perception ${ }^{13}$, but seeing was regarded as the nobler sense (cf. Diels 1903:173, 174; referred to by Michaelis 1981:315). Even Plato (Tim. $47 \mathrm{a}-\mathrm{b})$ regarded the ability to see as a gift from God and the foundation of philosophy. The philosophers were aware of the limitations of 'seeing' and 'hearing'; therefore, the 'verbs of seeing underwent an early transition from sensual to intellectual perception' (Michaelis 1981:319). For them sensual perception is limited. The senses are unable to grasp the true nature of things. The world of sense perception is seen in definite antithesis to the spiritual world. This relates to the doctrine of 'ideas' of Plato. Here ó $\tilde{\alpha} v$ (to see, perceive, Friberg et al. 2000:284) is contrasted with vociv (to comprehend, understand, Danker 2000:674). Hence, the world of the senses is perceptible or visible, but the world of ideas, the true reality, is only accessible to the voṽ (mind,

\footnotetext{
8. But if he be some deathless one come down from heaven, then do the gods herein deal with us strangely; for heretofore the gods have always shown themselves without disguise, and when we offer splendid hecatombs they sit beside us at the feast, even like ourselves' (Hom., Od. 7, 201ff.)
}

9.Michaelis (1981:320) refers to other texts that speak of the appearing of gods to men. He interprets these theophanies as visionary and hallucinatory experiences which are usually felt to be real by those who have experienced them. In relation to the accompanying circumstances as distinct from the actual declaration, what is to the accompanying circumstances as distinc

10.'He felt the change, wondered at it, and knew that the stranger was a god' (323325)

11.Empedocles of Acagras in Sicily was a philosopher and poet. He was one of the most important of the philosophers before Socrates, 492-432 BCE; viewed 24 August 2014, from http://www.iep.utm.edu/empedocl/

12.Plato is one of the world's best known and most widely read and studied philosophers. He was the student of Socrates and the teacher of Aristotle, 427-347 BCE; viewed 24 August 2014, from http://www.iep.utm.edu/plato/

13.'But beauty, as I said before, shone in brilliance among those visions; and since we came to earth we have found it shining most clearly through the clearest of our senses; for sight is the sharpest of the physical senses, though wisdom is not seen by it, for wisdom would arouse terrible love, if such a clear image of it were granted as would come through sight, and the same is true of the other lovely granted as would come through sight, and the same is true of the other lovely
realities; but beauty alone has this privilege, and therefore it is most clearly seen' realities; but beauty a
(Plat., Phaedr. 250d). intellect, Danker 2000:680). Only the voũ can comprehend God (Michaelis 1981:321). 'But it only is reality beheld' (Plat., Rep. 527e). For Plato:

[The mind] employs pure, absolute reason in his attempt to search out the pure, absolute essence of things, and who removes himself, so far as possible, from eyes and ears, and, in a word, from his whole body, because he feels that its companionship disturbs the soul and hinders it from attaining truth and wisdom. $(\text { Phaedo 66a })^{14}$

For Aristotle, a student of Plato, the true purpose of human life is achieved in contemplative self-giving to God, which is the worship of God. For Aristotle, to contemplate God is the way in which man should seek, as far as possible, to be like the immortals (Aristot., Eth. Nic. 10.7, p. 1177b.33). The divine mode of being and working consists in pure $\theta \varepsilon \omega \rho i \alpha$ (that which one looks at, sight, Danker 2000:454) (Aristot., Eth. Nic. 8, p. 1178 b.20ff.). ${ }^{15}$

Thus, for the Greeks it is generally accepted that $\theta \varepsilon$ ĩov [divine] is not something to be believed or heard; it is something to be seen, ${ }^{16}$ something revealed only through contemplation. This fact, first worked out in Greek philosophy, is also the core and essence of the Greek religion (cf. Plat., Phaedr. 248b), understood as piety and worship. In this central idea, Greek philosophy is simply transposing into an intellectual key, something that had been a historical reality in the religious life of the Greek people (Michaelis 1981:322).

There were also other philosophers who emphasised the ability of the mind/soul to see. According to Cicero ${ }^{17}$ (Tusc. 1.19.32ff.), there is naturally in human minds 'a certain insatiable desire to see truth' and also a desire for 'a more intuitive view of celestial things'. Seneca ${ }^{18}$ (Ep. Lucil. 87.21) indicates that only a pure and holy mind can comprehend God. ${ }^{19}$ Keener (2003:247) points out that, '[b]ecause Stoics believed that the action of a spirit attached to the eye generated vision, many Greeks did not perceive vision as simply passively receiving diffused light'. This could have increased the perception symbolised by the analogy of minds

14.Plato says (Plat., Phaedo 83a, b) that the lovers of knowledge "perceive that philosophy, taking possession of the soul when it is in this state, encourages it gently and tries to set it free, pointing out that the eyes and the ears and the other senses are full of deceit, and urging it to withdraw from these, except in so far as their use is unavoidable, and exhorting it to collect and concentrate itself within itself, and to trust nothing except itself and its own abstract thought of abstract itself, and to trust not existence; and to believe that there is no truth in that which it sees by other mean and which varies with the various objects in which it appears, since everything of that kind is visible and apprehended by the senses, whereas the soul itself sees
that which is invisible and apprehended by the mind.'

$15 . \ldots$ the activity of God, which is transcendent in blessedness, is the activity of contemplation; and therefore among human activities that which is most akin to the divine activity of contemplation will be the greatest source of happiness' (Aristot., Eth. Nic. 10.8.7).

16.It should be borne in mind that in many languages the verb for 'seeing' can be used to express a figurative meaning to understand. The context determines the semantic reference.

17.Cicero: Cicero was a Roman philosopher, politician, lawyer, 106-43 BCE; viewed 24 August 2014, from http://www.iep.utm.edu/cicero/

18.Seneca was a Roman Stoic philosopher, 1 BCE - 65 CE; viewed 29 July 2014, from http://www.iep.utm.edu/cicero/; http://plato.stanford.edu/entries/seneca/

19.'And how many bodies besides revolve in secret, never dawning upon human eyes? Nor has God revealed all things to man ... He is hidden from our eyes, He can be perceived only by thought' (Sen. Naturales Questiones VII, 30, 3). 
seeking divine light. The questions Epictetus ${ }^{20}$ (Diatribe 2.23.3) asks confirm this: 'Did God give you eyes to no purpose, did He to no purpose put in them a spirit ...?' Prior to these questions he stated that God has introduced man to be not only a spectator of God himself and his works, but that man also has to interpret these works (Diatribe 1.6.19). Consequently, Epictetus asks: '[W]here Zeus is already, and is present in his works, will you not yearn to behold these works and know them?' (Diatribe 1.6.24).

In later antiquity, there were also expressions in the GrecoRoman world about the impossibility of seeing the gods. Plutarch $^{21}$ (De Isis 79) renders the current philosophical paradigms of his day. Plutarch points out that a deity like the good god Osiris was 'at the remotest distance from the earth imaginable, being unstained and unpolluted, and clean from every substance that is liable to corruption and death'. For him the souls of mortals 'have no communion with God, except that they can reach to in conception only, by means of philosophy, as by a kind of an obscure dream'..$^{22}$ This seems to be a post-mortem ability of souls to behold the gods (esp. Osiris) (Plutarch, De Isis 78; Aune 1998:1180; Farrell 1992a:3-5).

Ovid (Metam. 15.60) refers to Pythagoras who taught about a man who 'had the gift of holding mental converse with the gods, who live far distant in the $\mathrm{h}[\mathrm{e}] \mathrm{igh}[\mathrm{th}]$ of heaven; and all that Nature has denied to man and human vision, he reviewed with eyes of his enlightened soul'. For Ovid ${ }^{23}$ (Metam. 15.62-64) a wise teacher can view the gods in his mind. Although they were remote from his eyes, they came close in his mind's eye. ${ }^{24}$ According to Orpheus 21, Ovid refers to the deity Tethys ${ }^{25}$ who was 'hid in a veil obscure from human sight'.

The author of a Sibylline oracle (related to Ovid) writes, 'I myself cannot see him; for around him a cloud has been fixed. For all mortals have mortal pupils in their eyes, too weak to see Zeus the ruler of all' (cf. Sib. Or. 3.17; 4.10-11). In Homeric Greek mythic literary tradition, human beings found it impossible to look gods in the face (Od. 16.179; Hymn 5 to Aphrodite 181-182). This was confirmed by Ovid's reference

20.Epictetus, a Greek philosopher, was an exponent of Stocism who flourished in the 2nd century, 55-135 CE; viewed 24 August 2014, from http://www.iep.utm.edu/ epictetu/

21. Plutarch was a Greek historian, biographer and essayist, 45-120 CE.

22.In Hymn to Apollo (2.9-10) Callimachus, Greek poet and scholar (310/305-240 $B C E)$, the most representative poet of the erudite and sophisticated Alexandrian school states the opposite: 'And ye, young men, prepare ye for song and for the dance. Not unto everyone doth Apollo appear, but unto him that is good. Whoso hath seen Apollo, he is great; whoso hath not seen him, he is of low estate.

23. He was a Roman poet best known for the Metamorphoses, a 15-book continuous mythological narrative written in the meter of epic, 43 BCE; viewed 29 July 2014 from http://global.britannica.com/EBchecked/topic/436057/Ovid

24.Xenophon (Memorabilia 1.4.[9]) adds to this in his reference that he does not see the master hand, but he can 'see the makers of things in this world'. According to Xenophon (Memorabilia Socratis, 4.3.63), the response of Socrates to a Greek seeker of a vision of God was that the entire universe reveals the works of the gods. According to Farrell (1992b:159), '... just as the Hebrew vision of humanity made in the image of God was susceptible to degeneration, so was the classical Greek seeing of the gods in their works.'

25.In Greek mythology, 'Tethys was the Titan goddess of the sources fresh water which nourished the earth. She was the wife of Okeanos'. She was invoked in classical Greek poetry, but not venerated in cult; viewed 20 August 2014, from http://www.theoi.com/Titan/TitanisTethys.html to the fatal death of Semele who saw the full majesty of Zeus ${ }^{26}$ (Ovid, Metam. 3.253-315; cf. Aune 1998:1180).

Correspondingly, in the Greco-Roman world, there were also those expressions in the mystery religions about the possibility of seeing the gods. In these religions, the visual plays a vital role. In some of these religions the ultimate goal is to see the god. This is evident at Eleusis in the seeing of sacred acts or in the Isis rites (Apul. Met. XI, 23), the seeing and worshipping at close proximity to the dii inferi (gods below) and dii superi (gods above). Apuleius ${ }^{27}$ claims that when he was initiated into the mysteries of Isis he approached the gods above and below. ${ }^{28}$ He further asserts that he 'worshipped them face to face ${ }^{29}$ (Apul. Met. 11.23-24). In the Mithras liturgy (Preis. Zaub. II, 485-732 in Betz 2003:115, 121; also cf. Michaelis 1981:322f.; Meyer 1976) the one who is reborn in the spirit receives ecstatic vision ${ }^{30}$ (cf. 508; 516f.) which is accomplished by the spirit (508). The 'immortal spirit' 'reappears here as the force bringing about the vision' $(516,520)$.

According to Hellenistic Gnosticism ${ }^{31}$ God is invisible by nature. This perception is also held in circles of later philosophy (Michaelis 1981:323). Gnosticism diverted from classical Greek thought that emphasises the invisible and other-worldly in its exclusion of matter as evil..$^{32}$ Gnosticism taught the pre-existence of the soul which fell into matter

26.' with [ which] insignia of his majesty, sad and reluctant, he appeared to her - her mortal form could not endure the shock and she was burned to ashes in his sight' (Metam. 3.253-315).

27. He was a Latin-language prose writer, 125-180 CE; viewed 24 August 2014, from https://www.google.co.za/\#q=Apuleius

28.In his commentary on 2 Corinthians Garland (1999:509) points out that visions were also part of the religious landscape of the Gentile world. It also functioned as part of initiations into mystery cults.

29.Aune (1998:1180) points out that this phrase relates closely to Paul's expression of the eschatological vision of God in 1 Corinthians 13:12, 'then we will see face to

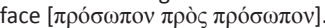

30.A surviving fragment of a Mithras liturgy depicts a visionary ascent to heaven: 'You will see (ơ?) yourself being lifted up and ascending to the height, so that you seem to be in midair ... you will see (ö $\psi$ ) all immortal things, for in that day and hour you will see (ő $\%$ ) the divine order of the skies: the presiding gods rising into

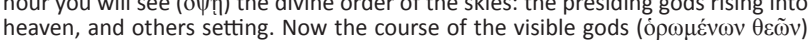
heaven, and others setting. Now the course of the visible gods (o $\rho \omega \mu \varepsilon v \omega v \theta \varepsilon \tilde{\varepsilon} v$ )
will appear through the disk of God ... And you will see (ö $\psi \eta \eta)$ the gods staring will appear through the disk of God ... And you will see (ö $\psi \eta \eta)$ the gods staring
intently at you and rushing at you ... Then you will see (ö $\psi \eta \eta)$ the gods looking intently at you and rushing at you ... Then you will see (oo $\psi$ ? $)$ the gods looking
graciously upon you and no longer rushing at you, but rather going about in their

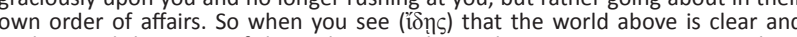
circling, and that none of the gods or angels are threatening you, expect to hear a great crash of thunder, so as to shock you ... and lafter you have said the second

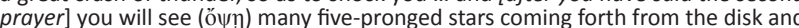
filling all the air. Then say again: 'Silence! Silence!' And when the disk is open, you will see (ö $\psi$ ) the fireless circle, and the fiery doors shut tight' (PGM IV.539-585) (Arnold 1995:126). Arnold has pointed out in his quotation that the verb óṕc (Appears repeatedly in the text and introduces what the initiate sees in the mystery appears repeatedly in the text and introduces what the initiate sees in the mystery

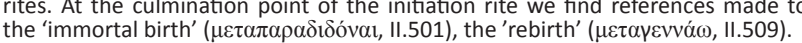

31.The Merriam-Webster dictionary defines Gnosticism as 'the thought and practice especially of various cults of late pre-Christian and early Christian centuries distinguished by the conviction that matter is evil and that emancipation comes through gnosis' (viewed 18 June 2014, from http://www.merriam-webster.com/ dictionary/gnosticism). Beyer (2014) defines Gnosticism as follows: 'Gnosticism encompasses a very wide range of beliefs and is better viewed as a collection of religions sharing some common themes rather than as one specific religion. There are two basic components to beliefs commonly labelled as Gnostic, although the importance of one over the other can vary immensely. The first is gnosis and the second is dualism' (viewed 18 June 2014, from http://altreligion.about.com/od/ alternativereligionsaz/a/gnosticism.htm).

32.Dodd (1968:153) elucidates on the difference between classical Greek thought and Gnostic thought as follows: 'The Gnostic form of knowledge is attached to the Greek insofar as it is a form of contemplation, $(\theta \varepsilon \omega \rho i ́ \alpha)$... But in its final form it lies beyond even the pure rational intuition of the eternal ideas which for Greek philosophy is the highest type of $\theta \varepsilon \omega \rho i \alpha$. It is unlike all other knowledge; no longer an achievement of the human intellect, but a gift of God. It makes a man no longer an achievement of the human intellect, but a gift of God. It makes a man no longer being like God, or even a god himself. This is not properly Greek.' 
at some time in the past. Visible reality was considered in the most negative of terms. ${ }^{33}$ Deliverance from matter was described as a reminiscence of the former life of the soul with God. According to Michaelis (1981:323), the Gnostics also believed that when man moves close to the divine nature and is consequently deified, he can see God. This vital change in humans is brought about by $\gamma v \tilde{\omega} \sigma \mathrm{l} \varsigma$ (comprehension or intellectual grasp of something, knowledge, Danker 2000:203) which enables the vision of God.

Visions also played a significant role in magical rites. The prayers of the magician are meant to direct the personal vision of gods and demons. ${ }^{34}$ According to Michaelis (1981:323), practices and formulae occur in magic papyri through which the magician attempts to force the gods and demons to manifest themselves and to subject themselves to control.

\section{To conclude}

This investigation attests a dichotomy of the visibility and invisibility of the gods in the Greco-Roman world. While some Greco-Roman sources emphasise that the gods are invisible, other sources, especially the mystery religions and Hellenistic Gnosticism, held the perception that the gods are visible. Owing to the importance attached to knowledge, intellect and the mind in Greek culture, it was the opinion of most authors 'that only the pure intellect could comprehend the divine ${ }^{\prime 35}$ (cf. Maximus of Tyre, Oration 11.9-10) (16 $^{36}$ and pure virtue could also see the divine.

Apart from Apuleius (who claimed that he worshipped the gods face to face) no other author has claimed that the gods could be seen face to face. Finally, in the Greco-Roman world Plutarch seems to be the only one to refer to a post-mortem ability of souls to behold the gods. Then there are also some minor differences that occur.

\section{The (in)visibility of God in Hellenised Judaism ${ }^{37}$}

Philo of Alexandria, a Jewish writer schooled in Hellenistic philosophy, attempted by means of allegorising to discover within the $\mathrm{LXX}^{38}$ all the truths of Hellenistic philosophy. $\mathrm{He}$ is indeed the best representative of Hellenistic Judaism

33.Opposite Gnosticism that rejected matter as evil, pantheism deified visible reality. illic According to Scott (1992:247), Hexpestic mystical vision of creation: 'I see (opmes) myself to be the All. I am in heaven and in earth, in water and in air, I am in beasts and plants, I am a babe in the womb, and one that is not yet conceived, and one that has been born; I am present everywhere.

34.Cf. Preis. Zaub., V, 54; VII, 319; cf. III, 699 as reference given by Michaelis (1981:324).

35.Maximus (Oration 11) distinguishes a hierarchy from God above to the earth below. He then explains this with a lucid image: 'The Great King (God) himself sits motionless (on his throne) ... As his partners in power, he has a whole host of visible and invisible deities, some gathered close round the vestibule of his throneroom ... others subordinate to these, and yet others further subordinate to them

36.See Keener (2003:423) on Greek views that seem to have varied.

37.In this subsection special reliance was placed on the works of Goodenough (1969) Hagner (1971:81-93), Keener (2003:248-249); Mackie (2012:147-179); Michaelis (1981:334-339) and the translated text of Philo by Yonge ([1854 [1993] 1996).

38. His doctrine of God is taken largely from the Old Testament (Hagner 1971:82).
(Hagner 1971:81). For Philo the seeing of God constitutes the pinnacle of human experience. For him it is the 'beginning and end of human happiness' (Quaest. in Ex. 2.51) and the 'most precious of all possessions' (Legat. 4). Goodenough (1969:7ff.; Hagner 1971:82) adds another perspective, 'that the Mystery, i.e. salvation in terms of the vision of God, is central to Philo.' Therefore, 'in many passages Philo accords the contemplative, a vision of God himself, the Existent One ( ò őv)' (Mackie 2012:148). Michaelis (1981:334) points out that in the works of Philo óów (including عĩov) is used predominantly for seeing, although ópó $\omega$ denotes especially spiritual seeing (as does ópađıкós exclusively).

For Philo, all vision in the present mortal state is incomplete. However, he is quite clear concerning what is possible and what is not.

It is God's existence that is apprehensible and not his essence. In the vision of God one apprehends that $\mathrm{He}$ is, not what $\mathrm{He}$ is. ${ }^{39}$ The chief end of man is thus to perceive God's existence directly, rather than indirectly through the shadows of his creation. (Hagner 1971:89; cf. Praem. 39)

The eye of the soul is overwhelmed (dazzled and confused) by the glory of God (Spec. Leg. 1.37); nevertheless, 'though we cannot attain to a distinct conception of the truly living God, we still ought not to renounce the task of investigating his character' (Spec. Leg. 1.40). A person should progress to any clearer vision; an ultimate vision of the divine was a reward for attaining perfection (Praem. 36; cf. Som. 72; see also Keener 2003:249).

Mackie (2012:148) refers to three key aspects of the visio Dei accounts of Philo: ${ }^{40}$ (1) the effectual means of the vision of God; (2) the methods evoking the visio Dei; and (3) the function and influence of the mysticism of Philo in the visio Dei.

\section{Participation of both humans and the divine}

Mackie (2012:153) points out that for Philo visionary ascent requires full dedication of a skilled person in the contemplation of the universe, philosophy and biblical interpretation (Spec. 3.1-6). Humans with such stature (as Philo described it) will experience dimmed visions when they should become distracted by any practical affairs of this world (Spec. 3:3-4). Philo emphatically stressed 'prepare thyself' which he further expressed as: 'change and adapt thyself to the vision of holiness' (Quaest. in Ex. 2.51).

For Philo God will manifest himself to the one who escapes from the body

when you have been released from the unspeakable bonds of the body and around the body, you will attain to an imagination of

39.An analysis of Mackie (2009:25-47) of the views of Philo about the identity of the Object which Philo saw in his visio Dei explanations revealed his conflictions about b joct which Philo saw in his visio Dei explanations revealed his confictions about who or what is seen. See also '... not indeed such a perception as should show 39, also 44). In Quaestiones et Solutiones in Exodum 54 he refers to God as ' $[t]$ he invisible and unseen one consists of incorporeal things'.

40.Philo also claims that God is entirely invisible (Det. 86-87; Mut. 7-9; Post. 15). 
the uncreated God ... showing that he is seen clearly by him who has put off mortal things, and who has taken refuge from this body in the incorporeal soul. (Det. 158)

Closely related to the freedom of the soul from the body, is the attainment of a likeness to God. Only the virtuous soul is permitted to proceed closer to God (cf. Opif. 144). The mind (voũs) that is able to attain vision into the great mysteries is one that is 'more perfect' and 'more highly purified' (Leg. All. III, 100).

Philo refers to Moses who said that only 'the most pure, and brilliant, and far-sighted eye of the soul, ... is permitted to behold God' (Conf. 92); the eye which receives the impression of the divine appearance is not the eye of the body, but the eye of the soul (Mut. 3). For Philo God is absolutely transcendent; therefore, He can be known only through ecstatic experienced mystical vision (Isaacs 1976:50) or the eye of the soul (Mut. 3). Thus, according to Philo's understanding of vision one can deduce that Moses perceived God not with physical eyes, but with eyes of the soul; and 'Israel' means 'the one who sees God' / 'seeing God' (Conf. 92, 146; Som. 1.171; Abr. 57).

From this brief discussion the visio Dei involves a full and continuous participation of both human and divine (cf. also similar accounts in Som. 2.232-233; Her. 69-70; Spec. Leg. 3:1-6; Gig. 29-31; and Plant. 18-26; as refer to by Mackie 2012:157).

\section{Techniques to evoke a visio $D e i^{41}$}

The preceding discussion demonstrates the role of the human effort and divine assistance in the visio Dei. Philo discusses the attainment of the visio Dei by way of three aspects: contemplative, ${ }^{42}$ moral and spiritual (cf. Mackie 2012:158).

Contemplation: In De Legatione ad Gaium (2.85) Philo refers to his custom of withdrawing from society to attend 'to some

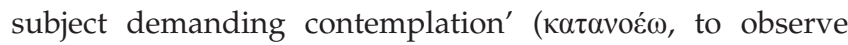
well, to understand, Liddell 1996:411). Philo's engagement in 'philosophy and the contemplation ( $\theta \varepsilon \omega \rho i ́ \alpha)$ of the universe and its contents' ${ }^{\prime 3}$ led to his ascent and noetic visuality (Mackie 2012:159). ${ }^{44} \mathrm{He}$ then describes himself as 'a soul possessed with divine inspiration' ( $\dot{\varepsilon} \pi 1 \theta \varepsilon 1 \alpha \sigma \mu$ ós, an appeal to the gods, Liddell 1996:202). In almost every book Philo refers to or discusses aspects of the contemplative process that can lead to a visual encounter with the 'Father and Creator, the uncreated God'.

\footnotetext{
41.Cf. Mackie (2012:158).

42.Mackie (2012:158) refers here to philosophical.

43.See the work of Deutsch (2008:83-103(87)) in which she notes the connection between contemplation and philosophy ( $\theta \varepsilon \omega \rho i ́ \alpha / \theta \varepsilon \omega \rho \varepsilon ́ \omega)$ in Spec. 3.1-2 (so also Opif. 77; Abr. 162-164; Mos. 2.66; Decal. 98) as referred to by Mackie 2012:159.

44.The practice of virtue is connected to noetic visuality in the following two contexts: (1) De Vita Mosis (1.190) describes that 'the intellect too of those persons who have tasted of holiness has a similar nature; for it has learned to look ( $\beta \lambda \dot{\varepsilon} \pi \omega$, gaze) upwards and to soar on high, and is continually keeping its eye fixed on sublime objects, and investigating divine things'. (2) De Specialibus Legibus (2.44-46) claims objects, and investigating divine things'. (2) De Specialibus Legibus (2.44-46) claims
that 'for all those men, whether among the Greeks or among the barbarians, who are practis[ion]ers of wisdom, living in a blameless and irreproachable manner ... having their souls furnished with wings, in order that thus hovering in the ai they may closely survey ( $\pi \varepsilon \rho 1 \alpha \theta \rho \varepsilon \dot{\varepsilon} \omega)$ all the powers above' (cf. Mackie 2012:160).
}

Moral: On at least four occasions in his writings Philo causally connects also the practice of virtue to the visio of

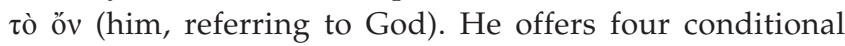
promises of a visio Dei to the virtuous noetic mystic. (1) The first statement is the most dynamic one. For Philo (Quaest. in Ex. 2.51; Mackie 2012:154) the mind must purify itself 'with holiness and every (kind of) purity'. One must 'change and adapt oneself to the vision of holiness' (Mackie 2012:155). If not, it will be unable to see God ('intelligible sun'). If consecration takes place, '[ $t]$ hen will appear to thee that manifest One'. (2) In De Ebriatate (83) Philo explicitly attributes the vision of God to a virtuous life: 'What among all the blessings that the virtues give can be more perfect than the sight of the Absolutely Existent?' (3) Similarly, in De Mutatione Nominum (82) Philo claims those who persevere in the pursuit and practice of virtue 'will be able to acutely and clearly behold the living God'. (4) In the fourth culminating statement Philo states that 'the beginning and end of happiness is to be able to see God'. Mackie (2012:155) points out that for Philo this is provisional for the consecration of oneself as a 'sanctuary and ... shrine of God'. Philo's depiction of the Therapeutae/ Therapeutrides emphasises their determined pursuit of virtue, the contemplative ascent, and the visio Dei (Vit. Cont. 25-27, 72, 90; cf. also Mackie 2012:167).

Spiritual: Although allegorical exegesis clearly played an essential role in the mystical practice of Philo, it is hardly connected to the visio Dei. However, Philo relates it closely to contemplative ascent and mystical visuality. In De Specialibus Legibus (3.1-6) this connection is explicit. The text 'begins with a detailed account of noetic ascent and mystical visuality and concludes with a recollection of inspired allegorical interpretation' (Mackie 2012:162; see also Borgen 1993:246-268). Such allegorical application with mystical visuality is also sensible in De Somniis 1.164-165; De Vita Mosis 1.158-59, 2.74-76; Quaestiones et Solutiones in Exodum 2.52; De Confusione Linguarum 95-96; De Vita Contemplativa $11-12,78 .^{45}$

\section{The connection of the mysticism of Philo with the visio Dei}

\section{The role which human reason plays in seeing God $^{46}$}

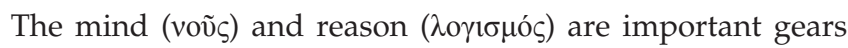
within the structure of Philo's thought. For Philo man performs best and approaches things divine, only when he rejects sense-perception and the material realm in favour of contemplating the immaterial via the mind and reason (cf. Mut. 3ff.; Hagner 1971:87). For him, through reason, humans can only achieve some part of the goal of visio Dei, 'For reason cannot make such advances as to attain to a thorough comprehension to God' (Leg. 6). He continues:

For the soul which perseveres in what is good, is able to comprehend all self-taught wisdom ... but is not yet able to see

45.See Mackie (2012:162-169) for a thorough discussion on these references. 46.See Mackie (2012:170). 
God who is the guide of wisdom ... inasmuch as he was invisible to all persons of intermediate character. (Det. 30)

Thus, for Philo, indeed, reason can take the believer into the lower mysteries, namely, apprehending the existence of God indirectly through his creation (Hagner 1971:87). However, it remains 'unable to apprehend the Existent alone by Itself and apart from all else, but only through Its actions, as either creative or ruling' (Abr. 112).

However, the existence of God is only knowledgeable directly through himself, even as all light is 'seen in consequence of light' (Praem. 45), while '[ $t]$ hey, then, who draw their conclusions in this manner perceive God in his shadow, arriving at a due comprehension of the artist through his works' (Leg. All. III, 99; see Hagner 1971:87).

But,

there is also a more perfect and more highly purified kind which ... receives a clear and manifest notion of the great uncreated, so that it comprehends him through himself, and comprehend his shadow, too, so as to understand what it is, and his reason too. (Leg. All. III, 100)

Eventually, through reason man cannot know God; personal intervention by God himself is required (Hagner 1971:87). This then boils down to the point that such divine intervention 'transcends both the powers of reason, and the mediating role of the Logos' (Hagner 1971:88). Such direct knowledge of God is only conceivable by means of a perception based on personal revelation. This knowledge from God may be defined more justifiably as an 'experience', although 'the rational faculty of man still has its part to play' (Hagner 1971:88).

Mackie (2012:170) is convinced that this proves that for Philo the human mind seems to be the place of the noetic ascent and visio Dei. Mackie's discussion of these texts exposed that cognitive and contemplative activities played a critical part in arousing the ascent and vision of God. Nevertheless, for Philo, this intellectual orientation, along with his repeated firmness that visions reveal only the existence of God and certainly not his essence (Praem. 39; Post. 15-16, 167-169; Fug. 141, 164-165; Spec. 1.40; Virt. 215), has directed some people to parallel the seeing of God with 'achieving a rational awareness of God's existence'.

\section{The visio Dei constitutes mystical experiences ${ }^{47}$}

Additional proof of a mystical vision of God in the visio Dei accounts of Philo may also be evident in the emotional and emperic experiential elements that appear in those explanations. Even though many of the visio Dei explanations are fairly unemotional and perceptive in orientation, quite an amount of texts occur throughout the corpus Philonum to contain emotional, emperic experiential, and ecstatic language and imagery (Opif. 69-71; Plant. 18-27; Praem. 38-39; Vit. Cont. 11-12; Ebr. 145-152) which embody, and

47.See Mackie (2012:174) even disembody, experiential appearances (Ebr. 145-152; also cf. Mackie 2012:174). ${ }^{48}$

\section{The visio Dei embedded in textual articulation}

Mackie (2012:176) assumes that the 'emotional content, experiential orientation, and visual imagery' found in some of the visio Dei accounts of Philo indicate that some kind of actual visual event is embedded in the text and constitutes 'its textual articulation'. These emotional, experiential and, in particular, visual elements are observable in De Opificio Mundi (69-71) referring to: the 'intelligible / mind' surmounted by the external senses 'yields to enthusiams, becoming filled with another desire, and a more excellent longing'. Borgen (1997:18) asserts that Philo accounts the aspired ascents of his mind (Spec. 3.1-6), the voice he heard in his soul (Cher. 27-29) ${ }^{49}$ and expresses that he was possessed not of one virtue only but of all, and that being so possessed of them, he constantly exhibits every one of them according to his power and opportunities' (Migr. 34-35). For Borgen (1997:18): 'The variety of forms of these ecstatic experiences supports the understanding that they refer to real experiences and are not only literary compositions made up by Philo as an author.'

From the above discussion it seems evident that Philo is 'both a philosopher of the transcendent and an exegete of Jewish biblical traditions'. He was definitely not always effective in his effort to reconcile these two incongruent professions and views (cf. Mackie 2012:177; also Goodenough 1963:26).

\section{To conclude}

In the writings of Philo, just as in the Greco-Roman sources, ambiguity occurs about the (in)visibility of God. This investigation has demonstrated that a visio Dei can, according to Philo, only be achieved through philosophical contemplation (philosophy), the practice of pure virtue (morality), and allegorical interpretation (spiritually) (cf. Hagner 1971:86-87). Thus, those who want to see God must be proficient in both philosophy and the sacred writings of Moses (cf. Mackie 2012:178). Philo remains true to the Old Testament. In Hellenistic Judaism, ${ }^{50}$ references of 'seeing God' could have referred to the mystical vision of God as perceived mentally or spiritually (Philo, Vit. Cont. 11-12; Mut. 81-82; Abr. 57-58; Origen, Contra Cels. 7.33-34). It is God's existence that is apprehensible, and not his essence. Inquiry into this facet of Philo's mystical praxis has further

48. An ambiguity ocurs in Philo about the 'seing' of God. He speaks at times..... though the vision of God was an impossibility: 'When ... the soul that loves God

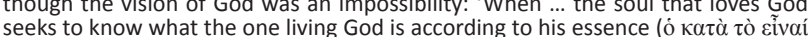

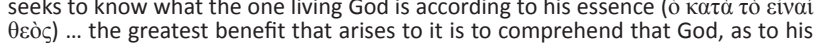
$\theta \varepsilon \dot{s})$ ) ... the greatest benefit that arises to it is to comprehend that God, as to his
essence, is utterly incomprehensible to any being, and also to be aware that he is invisible (dopó $\tau_{0} \varsigma$ )' (Post. 15; cf. Mut. 9). At the same time, however, he can speak much more hopefully: 'There is also a more perfect and more highly purified kind which has been initiated into the great mysteries, and which does not distinguish the cause from the things created as it would distinguish an abiding body from a shadow; but which, having emerged from all created objects, receives a clear and manifest notion of the great uncreated, so that it comprehends him through himself, and comprehends his shadow' (Leg. All. III, 100).

49.I have also, on one occasion, heard a more ingenious train of reasoning from my own soul' (Cher. I, 27).

50.According to Aune (1998:1180) the 'seeing God' in Hellenistic Judaism can refer to the mystical vision of God perceived mentally or spiritually (Philo, Vit. Cont. 11-12 Mut. 81-82; Abr. 57-58). According to him, Philo derives this notion from Platonic tradition. 
demonstrated its exceptional nature. Without doubt the visio Dei accounts of Philo denote attempts to 'express the inexpressible', the experience of actual, mystical visual encounters with God (cf. Mackie 2012:179).

\section{Conclusion}

\section{A comparison}

A comparison between the authors of the Greco-Roman world and Philo is certainly not an easy and simple task but is complicated by some factors. Firstly, the time interval of the Greco-Roman authors stretches over many centuries and that of Philo stretches only over a few decades. Secondly, Philo is an individual to be compared with a number of authors from different sectors of society. These two factors could have led to much diversity. Lastly, Philo's approach to the seeing of God is from the perspective of his belief in a monotheistic God, while that of the Greco-Roman authors (philosophers, poets, moralists, etc.) is from the perspective of polytheism (referring to gods and deities).

Fortunately, this polarity is bridged by the fact that Philo of Alexandria, a Jewish writer, was schooled in Hellenistic philosophy. This mandated him by means of allegorising to discover within the $\mathrm{LXX}^{51}$ all the truths of Hellenistic philosophy. Unfortunately, his efforts to reconcile the philosophy of the transcendent and his Jewish exegesis of biblical traditions were not always successful. This is clear from his reasoning about the vision of God. This becomes evident when his work is compared with Scripture itself.

Similarities between Philo and the Greco-Roman authors comprise, firstly, that with both a dichotomy occurs about the (in)visibility of the god(s) / God. In the Greco-Roman world, a certain group of the authors consulted, regarded the physical seeing of the nature of the divine as impossible while for others 'seeing' seems to be possible. For the Greeks it is typical that $\theta \varepsilon i$ ov (divine) is not something to be believed or heard; it is something to be seen. A god may appear in a human body or only to selected people, or can only be seen in a vision. Philo, probably the most important exponent in Hellenistic Judaism, agrees on this point. Hagner (1971:91) refers to the exhortation of Philo that everyone must seek God diligently. In the end, Philo had to confess that 'whether thou wilt find God when thou seekest is uncertain, for to many He has not manifested Himself, but their zeal has been without success all along' (Leg. All. III, 47). Maybe it can be deduced that in both cases it boils down to the statement made by Philo that ' $[i] n$ the vision of God one apprehends that $\mathrm{He}$ is, not what He is' (Praem., 39).

In both worlds it is also said that the deity is only visible to the extent in which the deity reveals him or herself intellectually to those with a pure mind and pure virtue (conduct). In both the Greco-Roman world and in Philo the emphasis is on virtue and purity of soul as the prerequisite for the attainment of vision. This resonates with Matthew 5:8; 1 Corinthians 13:12 and 1 John 3:2, which shows that these views could have influenced Jewish and Christian perspectives about the vision of God. Both worlds refer to the mystical vision of God

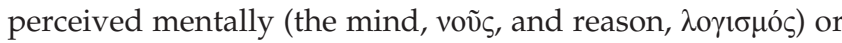
spiritually.

There are also dissimilarities: Philo remains true to the Old Testament. 'Similarities, especially with reference to Hellenistic religious philosophy, exist only at the terminological level and not in essential content' (Hagner 1971:93). Thus, for Philo, those who would see God must be versed in both philosophy as well as the sacred writings of Moses.

Finally, the mystical spirituality of Philo remains attractive. It evolves an inexorable bliss for scriptural exegesis. Philo continues to speak across millennia. He even, inspires contemporary readers to grapple with Scripture and strive for the greatest prize: 'to behold the living God, the being endowed with sight adequate to the clear comprehension of the only thing which is really worth beholding' (Mut. 82; cf. also Mackie 2012:179).

\section{Acknowledgements Competing interests}

The author declares that he has no financial or personal relationship(s) that may have inappropriately influenced him in writing this article.

\section{References}

Apuleius, 1878, The works of Apuleius, George Bell \& Sons, London, viewed 13 June 2014, from http://www.archive.org/stream/worksofapuleiuscO0apulrich\#page/ n7/mode/2up

Apuleius, 1975, 'The Isis-book' (Metamorphoses, Book 11), J. Gwyn Griffiths (ed.), E.J. Brill, Leiden.

Aristotle, 1934, Ethica Nicomachea, transl. H. Rackham, Heinemann, London, viewed 22 August 2014, from http://www.perseus.tufts.edu/hopper/text?doc=Perseus \%3Atext\%3A1999; 01.0054

Arnold, C.E., 1995, The Colossian syncretism: The interface between Christianity and the folk belief at Colossae, Mohr Siebeck, Tübingen.

Aune, D.E., 1998, Revelation 17-22, Word, Dallas, TX.

Balz, H.R. \& Schneider, G., 1990, Exegetical dictionary of the New Testament, Eerdmans, Grand Rapids, MI.

Betz, H.D., 2003, The 'Mithras Liturgy': Text, translation, and commentary, Mohr Siebeck, Tübingen.

Beyer, C., 2014, Gnosticism, viewed 15 July 2014, from http://altreligion. about.com/ od/alternativereligionsaz/a/gnosticism.htm

Borgen, P., 1993, 'Heavenly ascent in Philo: An examination of selected passages', in J.H. Charlesworth \& C.A. Evans (eds.), The pseudepigrapha and early biblical interpretation, pp. 246-268, JSOT Press, Sheffield.

Borgen, P., 1997, Philo of Alexandria, an exegete for his time, Brill, Leiden, viewed 18 August 2014, from http://books.google.co.za/books?hl=en\&|r=\&id= AGsQqjlJgQC\&oi= fnd\&pg=PR9\&dq=Borgen,+ Philo+of+Alexandria

Callimachus, 1921, Callimachus and Lycophron, transl. G.R. Mair, Heinemann, London, viewed 14 August 2014, from http://www.archive.org/stream/callimachus lycop00calluoft\#page/48/mode/2up

Cicero, n.d., Internet Encyclopedia of Philosophy (a peer-reviewed academic resource) edited by J. Fieser \& B. Dowden, viewed 24 August 2014, from http://www.iep. utm.edu/cicero/

Cicero, 1824, The Tusculan disputations of Cicero, transl. W.H. Main, Pickering, London, viewed 13 July 2014, from http://books.google.co.za/books?id=PUw AQ AAMAAJ\&printsec $=$ frontcover \&dq=Tusculan+Disputations.+Cicero

Cicero, 1971, Tusculanae disputationes, transl. J.E. King, Loeb classical library 141 Harvard University Press, Cambridge, MA.

Dahn, K., 1978, 'ópó $\omega$ ', in C. Brown (ed.), The international dictionary of New Testament theology, vol. 3, pp. 511-518, Zondervan, Grand Rapids, MI. 
Danker, F.W. (ed.), 2000, Greek-English lexicon of the New Testament and other early Christian literature, University of Chicago Press, Chicago, IL.

Deutsch, C., 2008, 'Visions, mysteries, and the interpretive task: Text work and religious experience in Philo and Clement', in F. Flannery, C. Shantz \& R.A. Werline (eds.), Experientia, Volume 1: Inquiry into religious experience in early Judaism and Christianity, pp. 83-103, SBLSymS 40, Society of Biblical Literature, Atlanta, GA

Diels, H.A., 1903, Die Fragmente der Vorsokratiker griechisch und deutsch, Weidmannsche buchhandlung, Berlin, viewed 13 July 2014, from https://archive. org/search.php?query=publisher\%3A\%22Weidmannsche+buch handlung $\% 22$ and https://archive.org/stream/diefragmenteder00krangoog \#page/n30/ mode/2up

Dodd, C.H., 1968, The interpretation of the Fourth Gospel, Cambridge University Press, Cambridge.

Empedocles, n.d., Internet Encyclopedia of Philosophy, viewed 24 August 2014, from http://www.iep.utm.edu/empedocl/

Epictetus, 1956, The discourses as reported by Arrian, the Manual, and the fragments, transl. W.A. Oldfather, Harvard University Press, Cambridge, MA, viewed 2 February 2014, from https://archive.org/stream/epictetusdiscour01epicuoft \#page/406/mode/2up and also http://classics.mit.edu/Epictetus/discourses. 1.one.html

Farrell, S.E., 1992a, 'Seeing the Father (Jn 6:46, 14:9)', Science et Esprit 44(1), 1-24.

Farrell, S.E., 1992b, 'Seeing the Father (Jn 6:46, 14:9)', Science et Esprit 44(2), 159-183.

Farrell, S.E., 1992c, 'Seeing the Father (Jn 6:46, 14:9)', Science et Esprit 44(3), 307-329.

Friberg, T., Friberg, B. \& Miller, N.F., 2000, Analytical lexicon of the Greek New Testament, Baker Books, Grand Rapids, MI.

Garland, D.E., 1999, 2 Corinthians, Broadman \& Holman Publishers, Nashville, TN.

Goodenough, E.R., 1963, An introduction to Philo Judaeus, Barnes \& Noble, New York.

Goodenough, E.R., 1969, By light, light: The mystic gospel of Hellenistic Judaism, Philo Press, Amsterdam

Hagner, D.A., 1971, 'The vision of God in Philo and John: A comparative study', Journa of the Evangelical Theological Society 14(2), 81-93.

Homer, Hymn 5 to Aphrodite, H.G. Evelyn-White (ed.), viewed 2 February 2014, from http://www.perseus.tufts.edu/hopper/text;jsessionid=2C43DAA0FE795F4F2B1B AFCB7C683471?doc=Perseus\%3atext\%3a1999.01.0137\%3ahymn\%3d5

Homer, 1900, The Odyssey, transl. S. Butler, A.C. Fifield, London, viewed 17 July 2014, from https://archive.org/stream/odysseyrenderediOOhomerich\#page/100/ mode/2up

Homer, 1945, The Odyssey, book 1, transl. A.T. Murray, Harvard University Press, Cambridge, MA, viewed 17 July 2014, from https://archive.org/stream/ odysseymurray01homeuoft\#page/n5/mode/2up

Isaacs, M.E., 1976, The concept of spirit: A study of pneuma in Hellenistic Judaism and its bearing on the New Testament, Heythrop College, London.

Keener, C.S., 2003, The Gospel of John: A commentary, vol. 1, Hendrickson, Peabody, MA.

Korteweg, T., 1979, 'The reality of the Invisible: Some remarks on St. John XIV 8 and Greek philosophic tradition', in M.J. Vermaseren (ed.), Studies in Hellenistic religions, pp. 60-62, Brill, Leiden.

Liddell, H.G., 1996, A lexicon: Abridged from Liddell and Scott's Greek-English lexicon, Logos Research Systems, Inc., Oak Harbor, WA.

Liefeld, W.L., 1978, ' $\beta \lambda \varepsilon \dot{\varepsilon} \omega^{\prime}$ ', in C. Brown (ed.), The international dictionary of New Testament theology, vol. 3, pp. 518-519, Zondervan, Grand Rapids, MI.

Mackie, S.D., 2009, 'Seeing God in Philo of Alexandria: The Logos, the Powers, or the Existent One?' Studia Philonica Annual 21, 25-47.

Mackie, S.D., 2012, 'Seeing God in Philo of Alexandria: Means, methods, and mysticism', Journal for the Study of Judaism 43, 147-179.

Maximus of Tyre, 1997, The philosophical orations, transl. M.B. Trapp, Clarendon Press, Oxford.
Meyer, M.W. (ed. and transl.), 1976, The 'Mithras liturgy', Scholars Press, Missoula, MT.

Michaelis, W., 1981, 'óó $\omega$ ', in G. Kittel \& G. Friedrich (eds.), Theological dictionary of the New Testament, vol. 5, pp. 315-367, Eerdmans, Grand Rapids, MI.

Ovid, 1922, Metamorphoses, transl. B. More, Cornhill Publishing Co., Boston, viewed 20 July 2014, from http://www. perseus.tufts.edu/hopper/text?doc=Perseus:text: 1999.02.0028 and http://www.perseus.tufts.edu/hopper/text?doc=Perseus \%3At ext\%3A1999.02.0028\%3Abook\%3D15\%3Acard\%3D60

Papyri graecae magicae, 1928, Die griechischen Zauberpapyri, Teubner, Stuttgart.

Philo, Quaestiones et Solutiones in Genesis, viewed 17 August 2014, from http:// archive.org/stream/questionsanswers00philuoft/questionsanswers00philuoft archive.org

Philo, Questions and answers on Exodus, transl. R. Marcus, Harvard University Press, Cambridge, MA, viewed 17 August 2014, from https://archive.org/stream/ questionsanswers02philuoft\#page/n5/mode/2up

Plato, Internet Encyclopedia of Philosophy, viewed 17 August, from http://www.iep. utm.edu/plato/

Plato, 1935, Republic, transl. P. Shorey, Heinemann, London, viewed 21 August 2014 from http://www.perseus.tufts.edu/hopper/text?doc=Perseus:text:1999.01.0168

Plato, 1962, Timaeus, J. Burnet (ed.), Clarendoniano, Oxonii, viewed 21 August 2014, from http://catalog.perseus.org/catalog/urn:cts:greekLit:tlg0059.tlg031.opp-grc1

Plato, 1964, Phaedrus, J. Burnet (ed.), Clarendoniano, Oxonii, viewed 17 July 2014, from http://www.archive.org/stream/operarecognovitb02platuoft\#page/253/ mode/2up

Plato, 1966, Phaedo, transl. F.H. North, Harvard University Press, Cambridge, MA, viewed 21 August 2014, from http://catalog.perseus.org/catalog/ MA, viewed 21 August 2014, from
urn:cts:greekLit:tlg0059.tlg004.perseus-eng1

Plutarch, 1874, Plutarch's morals, transl. W.W. Goodwin, Little, Brown, and Co., Boston, viewed 16 August 2014, from http://www.archive.org/stream/plutarchs moralst03plutuoft\#page/viii/mode/2up

Plutarch, 1909, Plutarch's morals, vol. 4, Of Isis and Osiris, or of the ancient religion and philosophy of Egypt, transl. W. Baxter, viewed 18 July 2014, from http://www. masseiana.org/plutarch.htm\#9

Rudberg, G., 1942, 'Hellenisches Schauen', Classica et Mediaevalia 5, 159-186.

Scott, W., 1992, Hermetica: The ancient Greek and Latin writings which contain religious or philosophic teachings ascribed to Hermes Trismegistus, Solos Press, Melksham, Wiltshire.

Seneca, n.d., The Stanford Encyclopedia of Philosophy (Winter 2012 Edition), Edward N. Zalta (ed.), viewed 24 August 2015, from http://plato.stanford.edu/entries/ seneca/

Seneca, 1910, Physical science in the time of Nero - Being a translation of the 'Quaestiones Naturales' of Seneca, transl. J. Clarke, Macmillan, London, viewed 'Quaestiones Naturales' of Seneca, transl. J. Clarke, Macmillan, London, viewed ge/304/mode/2up

Seneca, 1970, Ad Lucilium epistulae morales, transl. R.M. Gummere, Loeb classical library, Heinemann, London, viewed 12 June 2014, from https://archive.org/ stream/adlucilium epistu02sene\#page/n5/mode/2up

Sibylline Oracles, 1899, transl. M.S. Terry, Eaton \& Mains, New York, viewed 14 June 2014, from http://www.sacred-texts.com/cla/sib/sib.pdf

Sophocles, 1962, Antigone, transl. S. Francis, Macmillan, New York, viewed 13 June 2014, from http://catalog.perseus.org/catalog/urn:cts:greekLit:tlg0011.tlg002. opp-eng1

Stanford, W.B., [1983] 2014, Greek tragedy and the emotions: An introductory study, Routledge \& Kegan Paul, London

Xenophon, 1923, Memorabilia, E.C. Marchant(ed.), Heinemann, London, viewed 25May 2014, from http://www.perseus.tufts.edu/hopper/text?doc=Perseus\%3Atext\%3A 1999.01.0208

Yonge, C.D. (transl.), [1854] [1993] 1996, The works of Philo: Complete and unabridged, Hendrickson, Peabody, MA. 